\title{
Silicon balance in human volunteers; a pilot study to establish the variance in silicon excretion versus intake
}

\author{
Supannee Pruksa ${ }^{1}$, Atitaya Siripinyanond ${ }^{2}$, Jonathan J Powell ${ }^{3}$ and Ravin Jugdaohsingh ${ }^{3 *}$
}

\begin{abstract}
Background: Accumulating evidence suggests a role for silicon in optimal connective tissue health. Further proof of its importance/essentiality may be provided by studies involving imposed depletion followed by ${ }^{29} \mathrm{Si}$ challenge to estimate metabolic balance. Prior to conducting these expensive studies, we first established the variance of estimating normal Si excretion versus intake using a single oral dose of typical dietary Si, orthosilicic acid.

Methods: Healthy volunteers were recruited from Loei Rajabhat University, separated into two matched groups (three males and three females/group) and maintained on a standardized diet for the three study days. One group ingested $500 \mathrm{ml}$ water containing orthosilicic acid (28.9 mg Si) and the other group received $500 \mathrm{ml}$ water alone, all on a fasted stomach. Blood samples and total urine and faeces were collected over the $48 \mathrm{~h}$ post-dose period and $24 \mathrm{~h}$ before-hand (baseline) and analysed for silicon by inductively coupled plasma optical emission spectrometry.

Results: Serum Si analysis confirmed the ready absorption of silicon from the orthosilicic acid solution. Mean total urinary and faecal $\mathrm{Si}$ excretions over the $24 \mathrm{~h}$ post-dose period accounted for $57 \pm 9.5 \%$ and $39 \pm 9.4 \%$ of the ingested dose, respectively. Thus in total $96.3 \pm 5.8 \%$ of the ingested dose was recovered in faecal plus urinary excretions over the $24 \mathrm{~h}$ post-dose period.

Conclusions: We report that in healthy subjects (presumably in Si balance), the ingestion of a soluble dose of dietary Si results in the same quantity (within analytical error) being excreted within $24 \mathrm{~h}$. It is currently not known if this all originated from the dose solution or if there was some exchange with the body Si pool but, given the low variance in these silicon balance data, isotopic studies are now merited.
\end{abstract}

Keywords: Silicon, Orthosilicic acid, Absorption, Balance studies, Urine, Faeces

\section{Background}

Silicon is a critical element in the biology and/or survival of a number of lower life forms, including diatoms, certain sponges and many plants [1-4]. In humans and other mammals its role (if any) is less well defined despite being a common dietary trace element $(20-50 \mathrm{mg} /$ day is ingested by adults in western populations [5-8]). Indeed, the environmental ubiquity and limited (bio) chemistry of silicon have led to claims that its ingestion, ready absorption and excretion by mammals are all simply inevitable consequences of oral exposure to a small soluble molecule

\footnotetext{
* Correspondence: ravin.jugdaohsingh@mrc-hnr.cam.ac.uk

${ }^{3}$ MRC Human Nutrition Research, Elsie Widdowson Laboratory, Fulbourn Road, Cambridge CB1 9NL, UK

Full list of author information is available at the end of the article
}

(orthosilicic acid, $\left.\mathrm{Si}(\mathrm{OH})_{4}\right)$ that 'washes through' the system and has no biological function [9,10]. Against this, evidence is accumulating to suggest that, in mammals, silicon plays an important role in optimal connective tissue health [11-14]. Its exact role/function remains unestablished, but there is evidence to suggest it's involved in the synthesis and/or stabilisation of extracellular matrix components, namely collagen, and in the proliferation of connective tissue cells $[9,14]$. There is also evidence to suggest that silicon is carefully conserved when dietary deficiency is imposed $[15,16]$. To translate these findings to humans, and provide more evidence for its essentiality, balance studies using $\mathrm{Si}$ isotope(s) following a low silicon diet may demonstrate (i) retention of silicon following ingestion

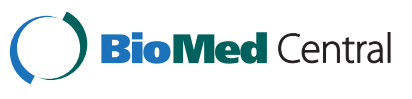

(c) 2014 Pruksa et al.; licensee BioMed Central Ltd. This is an Open Access article distributed under the terms of the Creative Commons Attribution License (http://creativecommons.org/licenses/by/2.0), which permits unrestricted use, distribution, and reproduction in any medium, provided the original work is properly cited. The Creative Commons Public Domain Dedication waiver (http://creativecommons.org/publicdomain/zero/1.0/) applies to the data made available in this article, unless otherwise stated. 
and (ii) whether ingested and absorbed silicon displaces some endogenous silicon or is simply washed through.

Despite the simple form of balance studies, where quantitative faecal and urinary excretion of a substance (and/or metabolites) are compared to the amount of substance ingested, they are fraught with difficulties [17]. Faecal collection and analysis is especially demanding: gastrointestinal transit times vary between individuals and temporary mucosal retention of a substance may also occur, adding further variability. Volunteers must provide complete collections and analysis of different fractions and sample types causes inevitable compound error.

For silicon, a basic human balance study, no matter how precise or accurate, would tell us little about the homeostasis of the element. If silicic acid is not utilised/ metabolised, but is washed through the system, then a perfect study would recover $100 \%$ of the ingested dose. On the other hand, if it were utilised and/or metabolised, a $100 \%$ recovery would still be expected assuming that volunteers are themselves in balance (i.e. not deficient). Nonetheless, the value of such a study would be to determine what sort of variance one might expect in balance if this were to be attempted in subsequent isotope and/or depletion studies (i.e. are these expensive and time consuming studies worth doing?). It would also have the added value of confirming whether urinary silicon, which is typically used to estimate silicon absorption in humans, is a valid measure for this purpose.

Here we sought to determine the balance in excretion of silicon (faecal and urinary) versus intake, using a single oral dose of silicic acid $(28.9 \mathrm{mg} \mathrm{Si})$ in human volunteers on a standardized diet.

\section{Subjects and methods Subjects}

Fourteen healthy volunteers (seven males and seven females, aged 18-23 years old) were recruited by advertisement on notice boards at Loei Rajabhat University, Thailand. Two subjects (one male and one female) were excluded due to fainting during blood collection at the screening stage. The remaining 12 subjects were self-reportedly healthy with normal renal function, as assessed by serum creatinine, and were not taking $\mathrm{Si}$ supplements and/or medicines containing $\mathrm{Si}$ and were not pregnant or lactating. The 12 subjects were divided into two groups of six, matched for age, body mass index (BMI) and male to female ratio. One group ingested $500 \mathrm{~mL}$ UHP water (Control group) and the other group $500 \mathrm{ml}$ of the $\mathrm{Si}$ supplement solution $(28.9 \mathrm{mg}$ $\mathrm{Si}$; Si-supplemented group). Anthropogenic data (age, height, weight, BMI and serum creatinine) were collected for each participant and there was no significant difference in subject characteristics between the two groups (Table 1). The study was conducted according to the guidelines laid
Table 1 Characteristics of the study volunteers

\begin{tabular}{|c|c|c|c|c|}
\hline \multirow[t]{2}{*}{ Characteristics } & \multicolumn{2}{|c|}{$\begin{array}{c}\text { Control group } \\
(3 \mathrm{M} \& 3 \mathrm{~F})\end{array}$} & \multicolumn{2}{|c|}{$\begin{array}{l}\text { Si-supplemented } \\
\text { group ( } 3 \text { M \& } 3 \mathrm{~F} \text { ) }\end{array}$} \\
\hline & Mean \pm SD & Range & Mean \pm SD & Range \\
\hline Age (y) & $21.2 \pm 1.9$ & $(18.1-23.1)$ & $21.0 \pm 1.3$ & $(19.0-22.0)$ \\
\hline Weight (kg) & $55.1 \pm 7.3$ & $(45.2-65.4)$ & $56.4 \pm 6.6$ & $(50.0-66.8)$ \\
\hline Height $(\mathrm{cm})$ & $163 \pm 10$ & $(155-176)$ & $165 \pm 8$ & $(157-176)$ \\
\hline $\mathrm{BMI}\left(\mathrm{kg} / \mathrm{m}^{2}\right)$ & $20.6 \pm 1.7$ & $(18.1-22.7)$ & $20.8 \pm 2.5$ & $(18.2-25.0)$ \\
\hline $\begin{array}{l}\text { Serum creatinine } \\
(\mathrm{mg} / \mathrm{dL})\end{array}$ & $0.92 \pm 0.15$ & $(0.80-1.10)$ & $0.88 \pm 0.15$ & $(0.80-1.10)$ \\
\hline \multicolumn{5}{|l|}{$\begin{array}{l}\text { Baseline } 24 \mathrm{~h} \\
\text { Si excretion: }\end{array}$} \\
\hline $\begin{array}{l}\text { Urine } \\
\text { (mg/24 h) }\end{array}$ & $12.48 \pm 2.26$ & $(9.72-15.31)$ & $12.93 \pm 2.85$ & $(9.11-16.34)$ \\
\hline $\begin{array}{l}\text { Faeces } \\
(\mathrm{mg} / 24 \mathrm{~h})\end{array}$ & $9.50 \pm 1.41$ & $(7.99-11.48)$ & $9.35 \pm 2.01$ & $(6.68-11.47)$ \\
\hline
\end{tabular}

${ }^{1}$ Normal creatinine levels: male $0.9-1.3$, female $0.6-1.1 \mathrm{mg} / \mathrm{dL}$.

down in the Declaration of Helsinki and was approved by the Loei Rajabhat University Local Research Ethics Committee. All participants gave signed written consent following oral and written explanation of the study details.

\section{Materials}

Glassware was avoided throughout the study to prevent $\mathrm{Si}$ contamination. Ultra high purity (UHP) water was from a water purifier (Labscan Asia Co Limited, Bangkok, Thailand). The stock basic sodium silicate solution was from Lakehead University, Canada (Professor Stephen Kinrade). The stock silicon ICP standard solution $(1,000 \mathrm{mg} / \mathrm{L} \mathrm{Si})$ was from Merck Ltd (Poole, UK). Nitric acid $\left(65 \%(\mathrm{w} / \mathrm{v}) \mathrm{HNO}_{3}\right)$ and hydrochloric acid (37\%) were high purity from RCI Labscan Limited (Bangkok, Thailand). Polypropylene tubes (15 and $50 \mathrm{~mL}$ ) were from Elkay Laboratory Products UK Ltd (Basingstoke, UK). Polypropylene bottles (30 and 2,000 $\mathrm{mL}$ ) were from VWR International (Poole, UK). All intravenous catheters $(1.2 \times 45 \mathrm{~mm})$ and plastic syringes were from Nipro Ltd (Pranakhonsriayuthaya, Thailand). Pasteur pipettes $(3.5 \mathrm{~mL})$, used for sample transfer, were from Greiner Bio-One Limited (Stonehouse, UK). Pipette tips (100-1,000 $\mu \mathrm{L}$ ) were from Hycon (Biomed C. Ltd., Bangkok, Thailand).

\section{Preparation of Si supplement}

The Si supplement (orthosilicic acid solution, OSA) was prepared fresh, just prior to ingestion, by dilution of the stock basic sodium silicate solution $(1.58 \mathrm{~mol} \mathrm{Si} / \mathrm{L}$ or $45.72 \mathrm{~g} \mathrm{Si} / \mathrm{L}$ ) into UHP water and $\mathrm{pH}$ neutralization to 7.2 with $\mathrm{HCl}$. The Si concentration in the test solution ( $2.06 \mathrm{mmol} / \mathrm{L}$ or $57.78 \mathrm{mg} / \mathrm{L}$ ) was confirmed by inductively coupled plasma - optical emission spectrometry (ICP-OES; Perkin Optima, model 2100 DV). 


\section{Study design}

Twenty four hours prior to ingestion of the test solutions (study day 0), all subjects collected $24 \mathrm{~h}$ urines (as two $12 \mathrm{~h}$ collections) and faeces (one $24 \mathrm{~h}$ collection) for baseline Si measurements. All subjects fasted overnight from $22.00 \mathrm{~h}$ and reported, still fasted, to Loei Rajabhat University the following morning (study day 1 ) at $08.00 \mathrm{~h}$ where they emptied their bladder and bowel into containers (part of $24 \mathrm{~h}$ baseline collections) and had an intravenous catheter inserted into a forearm vein. Two $10 \mathrm{~mL}$ blood samples were collected into polypropylene tubes for baseline Si measurements. Subjects were given $500 \mathrm{~mL}$ of the test solution ( $\mathrm{Si}$ supplement or water) and asked to consume it as quickly as possible, i.e. within 10-15 min. Thereafter, further blood samples $(10 \mathrm{~mL})$ were collected at $30 \mathrm{~min}$ intervals for the first $2 \mathrm{~h}, 1 \mathrm{~h}$ intervals for next $4 \mathrm{~h}$ and finally at 9, 12, 24 and $48 \mathrm{~h}$ post-ingestion (the latter two were collected at $08.00 \mathrm{~h}$ on study days 2 and 3). Subjects also collected their urine as four $3 \mathrm{~h}$ collections (i.e. 08.00-11.00 h, 11.00-14.00 h, 14.00-17.00 h and 17.00-20.00 h) plus three $12 \mathrm{~h}$ collections (i.e. $20.00 \mathrm{~h}$ study day 1 to $08.00 \mathrm{~h}$ study day 2, $08.00 \mathrm{~h}$ study day 2 to $20.00 \mathrm{~h}$ study day $2,20.00 \mathrm{~h}$ study day 2 to $08.00 \mathrm{~h}$ study day 3) in separate pre-weighed, pre-cleaned plastic containers. Additionally, subjects also collected all their faeces over the $48 \mathrm{~h}$ post-dose period as two $24 \mathrm{~h}$ collections (08.00 h study day 1 to 08.00 h study day $2,08.00$ h study day 2 to $08.00 \mathrm{~h}$ study day 3 ) in containers provided. A summary of the study design is shown in Figure 1.

\section{Standardized meals}

All 12 participants received the same meals, and the same amount of each meal, for breakfast, lunch and dinner during the study/sample collection periods: namely, study day 0 (baseline collection), study day 1 and study day 2. Males and females received the same amount of each meal and therefore their silicon intakes were identical. The contribution of $\mathrm{Si}$ from the three meals was estimated from reference food $\mathrm{Si}$ values $[5,18]$ or from direct analysis (i.e. drinking water) and was, on average, $24 \mathrm{mg} \mathrm{Si}$ /day over the study period (Table 2). Meals were eaten as follows: breakfast at $08.00 \mathrm{~h}$ for study day 0 and study day 2 , and at $12.30 \mathrm{~h}$ for study day 1 as subjects remained fasted until then; lunch at $12.30 \mathrm{~h}$ for study day 0 and study day 2 , and at $16.30 \mathrm{~h}$ on study day 1 ; dinner at $18.30 \mathrm{~h}$ for study day 0 and study day 2 , and at $20.30 \mathrm{~h}$ on study day 1 . The total intake of Si from the meals on study day 1 was $23.86 \mathrm{mg}$. All subjects ate at the same times.

\section{Sample preparations}

Serum samples Blood samples were collected in $15 \mathrm{~mL}$ polypropylene tubes and left to stand for at least $1 \mathrm{~h}$ at room temperature to clot. The clotted blood samples were then centrifuged (Hettich Zentrifugen, Tuttlingen, Germany) at 3,000 rpm for $10 \mathrm{~min}$ at room temperature. The separated serum fractions were collected into new $15 \mathrm{~mL}$ polypropylene transport tubes and stored at $-20^{\circ} \mathrm{C}$ until elemental analysis. Prior to analysis, the serum samples were thawed at room temperature $\left(23^{\circ} \mathrm{C}\right)$ and then diluted $1+4$ with $0.25 \%(\mathrm{v} / \mathrm{v})$ high purity $\mathrm{HNO}_{3}$.

Urine samples Urine collections were weighed and volumes calculated assuming a density of 1 . After thorough mixing, a $10 \mathrm{~mL}$ homogenous sample was collected into a $30 \mathrm{~mL}$ polypropylene bottle and diluted with equi-volume $0.7 \%(\mathrm{v} / \mathrm{v})$ high purity $\mathrm{HNO}_{3}$ (i.e. $1+1$ dilution) to reduce any precipitation during storage [19]. The diluted samples were stored at $4^{\circ} \mathrm{C}$ until elemental analysis. Prior to analysis, the diluted samples were incubated overnight in their closed containers at $40^{\circ} \mathrm{C}$ in an oven to dissolve any precipitates that may have formed during storage [19]. Samples were cooled to room temperature prior to total elemental analysis for $\mathrm{Si}$.

Faecal samples Faecal collections were weighed and after thorough manual mixing with a disposable wooden spatula,

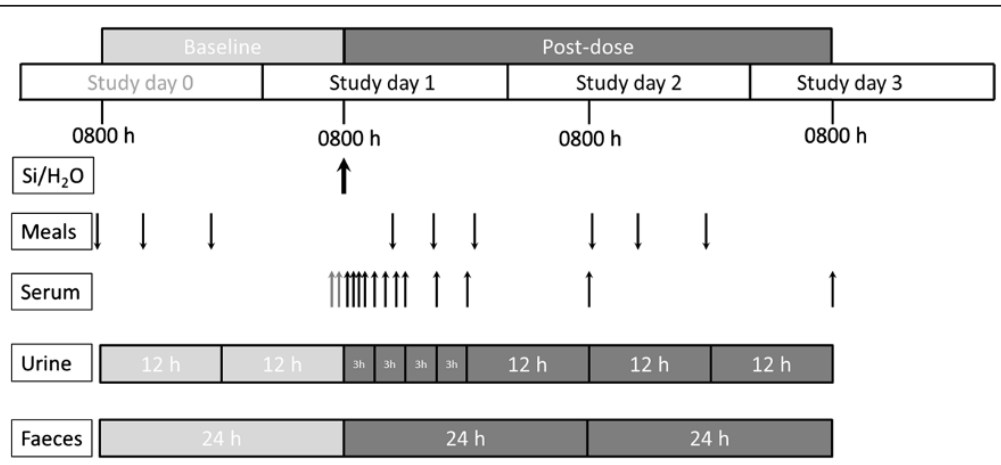

Figure 1 Study design. Summary of the timing of ingestion of the test solutions (Si-supplement or ultra-high purity water; Si/ $\mathrm{H}_{2} \mathrm{O}$ shown by thick black arrow) and standardised meals (down arrows), and the collection of serum (thin up arrows), urine and faecal samples (collection periods indicated). Pre-dose (baseline; light grey) and post-dose (dark grey) collections are indicated. 
Table 2 Estimated silicon content ${ }^{1}$ of the meals ( $\mathrm{mg} \mathrm{Si} / \mathrm{meal}$ ) provided to all participants during the study period

\begin{tabular}{llccc}
\hline Meals & Components & Day $\mathbf{0}^{\mathbf{3}} \mathbf{( m g ~ S i )}$ & Day $\mathbf{1}$ (mg Si) & Day $\mathbf{2}(\mathbf{m g ~ S i})$ \\
\hline Breakfast & Egg fried rice with pork/chicken, orange juice, drinking water ${ }^{2}$ & 6.78 & 7.70 & 7.34 \\
\hline Lunch & Rice with chicken, drinking water ${ }^{2}$, yogurt, sponge cake & 7.59 & 7.33 & 9.01 \\
\hline Dinner & Rice with stir-fried pork/chicken with kale, melon, drinking water ${ }^{2}$ & 9.93 & 7.43 & 7.97 \\
\hline & Total Si intake per day & 24.29 & 23.86 & 23.91 \\
\hline
\end{tabular}

${ }^{1}$ Calculated from reference food Si values $(5,18)$.

2Produced from tap water by reverse osmosis ( $\mathrm{Si}$ concentration $=0.67 \mathrm{mg} \mathrm{Si} / \mathrm{L}$ as analysed here by ICP-OES).

${ }^{3}$ Day $0=$ pre-dose, baseline collection period, conducted $24 \mathrm{~h}$ prior to ingestion of the test solutions on day 1.

a homogenous sample (from each collection) was collected into a $50 \mathrm{~mL}$ polypropylene bottle and stored at $-20^{\circ} \mathrm{C}$. Prior to analysis, approximately $0.25-0.5 \mathrm{~g}$ of the faecal samples was digested with an equi-volume $(5 \mathrm{~mL})$ of concentrated $(65 \%(\mathrm{w} / \mathrm{v})) \mathrm{HNO}_{3}$ and hydrogen peroxide (30-40\%) at room temperature for $24 \mathrm{~h}$. These were incubated at $40^{\circ} \mathrm{C}$ until total digestion was obtained. Sample (acid) blanks were similarly prepared. An aliquot $(1 \mathrm{~mL})$ of the digested samples and sample blanks were diluted with $5 \mathrm{~mL}$ UHP water prior to total element analysis for $\mathrm{Si}$.

\section{Total elemental analysis}

Total elemental analysis for $\mathrm{Si}$ was carried out (at $251.611 \mathrm{~nm}$ ) by ICP-OES; Perkin Elmer Optima model 2100 DV, equipped with a Cross flow nebuliser and Cyclonic spray chamber. Nebulizer flow rate was $0.8 \mathrm{~L} / \mathrm{min}$. Peak area was 7.7 points and integration times were $20 \mathrm{sec}-$ onds/analysis/element. Sample flow rate was $2 \mathrm{~mL} / \mathrm{min}$. Matrix matched standards, sample blanks, diluents and quality control samples were run alongside the samples.

Serum, urine and faecal samples The diluted serum, urine, and faecal samples from the same subject were analyzed together in the same batch. Sample-based standards were prepared in the pooled diluted sera, baseline urine, or baseline faecal samples using the $1,000 \mathrm{mg} / \mathrm{L} \mathrm{Si}$ ICP standard solution.

Test solutions The Si supplement solution, UHP water and drinking water (part of standardized meals) were also analyzed for Si by ICP-OES using appropriate standards.

Sample diluents As the serum and urine samples were diluted with $0.25-0.7 \% \mathrm{HNO}_{3}$, Si content of the acid diluents was also measured by ICP-OES. Although minor, this contaminant $\mathrm{Si}$ was subtracted from each of the sample data.

\section{Statistical analysis}

Sample size (power) calculation was based on the available data on urinary Si excretion [20]. No previous data exist for faecal Si excretion. A relative standard deviation $(\sigma)$ of 9.4\% [20] was estimated for the variance in urinary $\mathrm{Si}$ and a potential difference of $20 \%$ for the excretion of urinary $\mathrm{Si}$ between the $\mathrm{Si}$ supplement and water test solutions was assumed, with $90 \%$ power at a $5 \%$ significance level. Sample size formula for the difference of two independent means was used for the calculation and six completed subjects were the minimum required for each test solution.

Area under the curve (AUC) of serum Si was calculated using the linear trapezoidal rule [21]. Due to a small number of subjects in each group, differences in serum AUC, and in urinary and faecal excretions of $\mathrm{Si}$, between the two groups (Si vs. control), were analysed non-parametrically using the Mann-Whitney Rank test. Statistical analyses were two sided and a $P$ value $\leq 0.05$ was considered significant. SPSS for Windows version 13.0 (SPSS Inc., Chicago, Illinois, USA) was used for all statistical analyses.

\section{Results}

Gender specific analysis showed no significant difference in silicon absorption, excretion (urinary and fecal) and balance between male and female subjects and so the combined (pooled) dataset is shown for clarity and because of the small number of subjects.

\section{Serum Si absorption}

Mean baseline serum $\mathrm{Si}$ concentrations were similar in the control and the Si-supplemented groups $(114 \pm 17 \mu \mathrm{g} / \mathrm{L}$ (range $85-130 \mu \mathrm{g} / \mathrm{L}$ ) vs. $112 \pm 26 \mu \mathrm{g} / \mathrm{L}$ (range $83-$ $148 \mu \mathrm{g} / \mathrm{L})$ ) and remained close to baseline in the control group following ingestion of UHP water (Figure 2A). In contrast, and as expected, serum Si concentrations increased markedly above baseline following ingestion of the orthosilicic acid solution (28.9 $\mathrm{mg} \mathrm{Si}$ in UHP water) in the $\mathrm{Si}$-supplemented group, with peak $\mathrm{Si}$ concentration $(206 \pm 48 \mu \mathrm{g} / \mathrm{L}$; range: $133-250 \mu \mathrm{g} / \mathrm{L})$ observed 1 to 2 hours post-ingestion (Figure $2 \mathrm{~A}$ ). Thereafter, serum Si concentrations began to drop rapidly back towards baseline concentrations. However, the ingestion of meals at $4.5 \mathrm{~h}$ and $8.5 \mathrm{~h}$ post-dose maintained serum $\mathrm{Si}$ concentrations above baseline in the Si-supplemented group and increased Si concentration above baseline in the control group, until $12 \mathrm{~h}$ post-dose. Area under the curve (AUC) of serum $\mathrm{Si}$ over the $24 \mathrm{~h}$ period was not significantly different between the two test solutions. However, AUC for the 

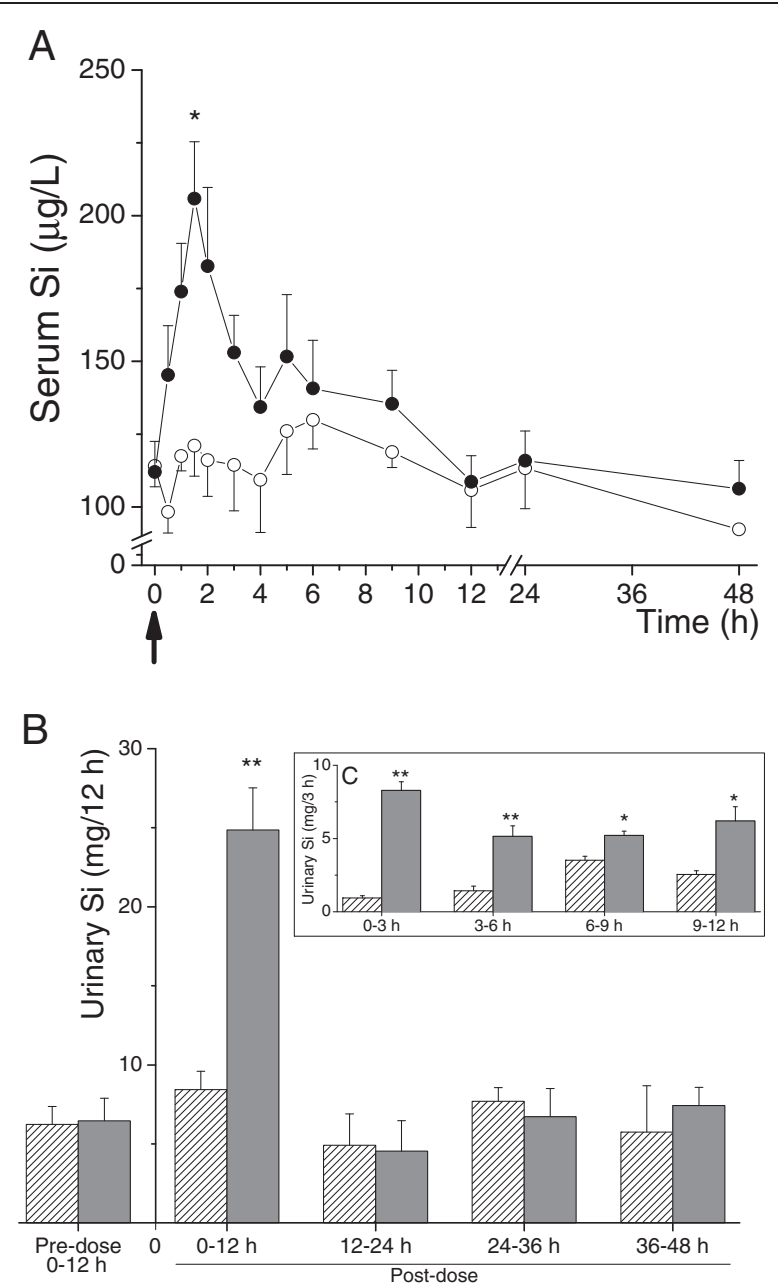

Figure 2 Serum Si absorption and urinary Si excretion following ingestion of the test solutions. (A) Serum silicon absorption. Serum Si following ingestion of UHP water alone (O-O; Control group) or following ingestion of UHP water containing 28.9 mg Si as orthosilicic acid (- $\bullet$ Si-supplemented group). Data are means \pm SE of 6 subjects per group. The large arrow below the $x$-axis indicates the time of ingestion of the test solutions (i.e. $\mathrm{t}=0$ ). ${ }^{*} P=0.009$ (Mann-Whitney Rank test). (B and $\mathbf{C}$ ) Urinary silicon excretion. Urinary excretion of Si following ingestion of UHP water alone (stripped bars; Control group) and UHP water containing $28.9 \mathrm{mg}$ Si as orthosilicic acid (grey bars; Si-supplemented group). (B) Silicon levels in the 12-h urine collections over the $48 \mathrm{~h}$ study period. (C) The insert shows more detailed analysis of Si output over the first $12 \mathrm{~h}$ following ingestion of the test solutions. Data are means \pm SD of 6 subjects per group. *P $=0.009,{ }^{* *} P=0.002$ (Mann-Whitney Rank test).

period prior to breakfast, i.e. $0-4$ h post-dose, was significantly higher following ingestion of orthosilicic acid solution, compared to UHP water alone $(648 \pm 137 \mathrm{mg} \mathrm{h} / \mathrm{L}$ (range $459-819 \mathrm{mg} \mathrm{h} / \mathrm{L}$ ) vs. $453 \pm 104 \mathrm{mg} \mathrm{h} / \mathrm{L}$ (range $319-630 \mathrm{mg} \mathrm{h} / \mathrm{L}) ; P=0.04$ ).

\section{Urinary Si excretion}

Mean total baseline $24 \mathrm{~h}$ urinary Si excretion was $12.48 \pm$ 2.26 (range $9.72-15.31$ ) and $12.93 \pm 2.85$ (range 9.11 16.34) $\mathrm{mg}$, respectively, in the control and Si-supplemented groups and did not change markedly in the control group following ingestion of UHP water $(13.34 \pm 2.48 \mathrm{mg}$; range 11.36 - $18.21 \mathrm{mg})$. In contrast, in the Si-supplemented group, ingestion of the orthosilicic acid solution $(28.9 \mathrm{mg}$
$\mathrm{Si}$ in UHP water) led to a marked increase in urinary excretion of $\mathrm{Si}$ in the $0-12 \mathrm{~h}$ post-dose collection $(P=0.002$; Figure $2 \mathrm{~B}$ ). A more detailed analysis of the $0-12 \mathrm{~h}$ collection in the $\mathrm{Si}$-supplemented group showed that the peak increase in Si output was at 0-3 h post-dose (Figure 2C). Again, the ingestion of meals at $4.5 \mathrm{~h}$ and $8.5 \mathrm{~h}$ post-dose maintained urinary Si output above baseline in the 6-9 $\mathrm{h}$ and $9-12 \mathrm{~h}$ post-dose collections, as clearly mirrored in the control group (Figure 1C). Urinary $\mathrm{Si}$ output in the remaining collections (12-24 h, 24-36 h and 36-48 h), were comparable to baseline levels and similar between the two groups.

The increase in urinary Si output in the Si-supplemented group over the $24 \mathrm{~h}$ post-dose period following ingestion 
of the orthosilicic acid solution (i.e. over and above baseline urinary Si excretion) was $16.5 \pm 2.7 \mathrm{mg}$ (range 14.4$20.5 \mathrm{mg}$ ) and this accounted for $57.0 \pm 9.5 \%$ (range $49.8-$ $71.0 \%)$ of the supplemental $\mathrm{Si}$ dose $(28.9 \mathrm{mg})$ ingested.

\section{Faecal Si excretion}

Mean total baseline $24 \mathrm{~h}$ faecal excretion of $\mathrm{Si}$ was $9.5 \pm 1.4$ (range $8.0-11.5$ ) and $9.4 \pm 2.0$ (range $6.7-11.5$ ) $\mathrm{mg}$, respectively, in the control and $\mathrm{Si}$-supplemented groups (Figure 3) and did not change markedly in the control group following ingestion of UHP water. However, the ingestion of the orthosilicic acid solution led to a significant increase in faecal Si content in the $24 \mathrm{~h}$ post-dose collection compared to baseline ( $P=0.002$; Figure 3$)$. This increase in faecal $\mathrm{Si}$ excretion in the $\mathrm{Si}$-supplemented group, by + $11.4 \pm 2.7 \mathrm{mg}$ (range $+7.6-14.9 \mathrm{mg}$ ) over $0-24 \mathrm{~h}$ period, accounted for $39.3 \pm 9.4 \%$ (range: $26.4-51.6 \%$ ) of the ingested supplemental Si dose (28.9 mg).

\section{Silicon balance}

In the Control group urinary and faecal $\mathrm{Si}$ excretion over the $24 \mathrm{~h}$ post-dose period accounted for $99.6 \pm 8.1 \%$ (range $90.6-112.9 \%$ ) of the total Si intake over that period, whilst in the $\mathrm{Si}$-supplemented group average recovery from urine and faeces was slightly less at $94.8 \pm 9.4 \%$ (range 83.3 105.6\%; Table 3). Of the supplemental Si dose ingested (28.89 mg), $27.83 \pm 1.67$ (range 25.6 - 29.5) mg (or $96.3 \pm$ $5.8 \%$; range 88.5 - $102.2 \%$ ) was recovered from urinary and faecal excretion over the $24 \mathrm{~h}$ post-dose period in the Si-supplemented group.

\section{Discussion}

The present study investigated the balance in excretion of silicon versus its intake, using a single dose of typical

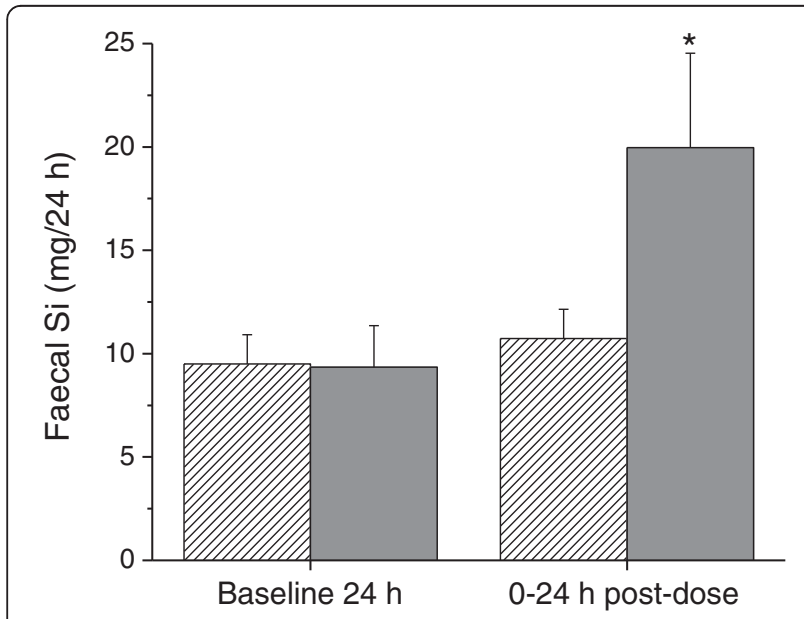

Figure 3 Faecal silicon excretion. Mean ( \pm SD) faecal excretion of Si following ingestion of UHP water (stripped bars) and UHP water containing 28.9 mg Si (grey bars) in six subjects. * $P=0.002$ (MannWhitney Rank test). dietary silicon $(28.9 \mathrm{mg})$ in healthy human volunteers on a standardized diet. Our results show that, within error, all $(96 \pm 6 \%)$ of the ingested dose was excreted in urine and faeces over the $24 \mathrm{~h}$ post-dose period. Whether it is, fully, the same Si being excreted that is being absorbed will need to be addressed with a different study design. However, to get within $5 \%$ of intake with variance of $\sim 6 \%$ is better than may have been expected, especially with the complexities of faecal and urine collection and analysis $[17,22]$. Typical recovery from such studies, even with radiolabelled compounds, can be $80 \%$ or less, much less than from animal studies [23,24]. The high renal clearance of $\mathrm{Si}$ and the lack of interaction with serum proteins probably aids recovery $[25,26]$.

As mentioned previously, $100 \%$ recovery is expected if (a) $\mathrm{Si}$ metabolism is regulated but the subjects are in $\mathrm{Si}$ balance (i.e. are Si replete) or (b) if Si has no active biological function and thus Si metabolism is not regulated at all. This study cannot prove which is true but we believe that the former is more likely based on previous murine data where urinary Si output was found to be conserved in Si-deprived animals to maintain tissue Si levels [15]. To now show this in humans we will need to repeat the study with subjects who are in negative Si balance (i.e. Si deplete at the start of the supplementation period by prior dietary Si deprivation for a week or so). Supplementation with the $\mathrm{Si}$ dose should then result in less Si being excreted, as more is retained to replenish the depleted body $\mathrm{Si}$ pool, compared to a Si-replete group.

Secondly, from this current work, we cannot be certain that the $\mathrm{Si}$ excreted in urine and faeces all originated from the ingested $\mathrm{Si}$ dose and that there was not some exchange with the body Si pool- as for example occurs with dietary phosphate [27]. This can only be answered with an isotope label study, where isotopic $\mathrm{Si}$ is used for the dose solution to discriminate it from $\mathrm{Si}$ of the body pool and from dietary sources (i.e. the meals ingested). However this is also not straight forward. ${ }^{31} \mathrm{Si}$ and ${ }^{32} \mathrm{Si}$ are both radioactive and would result in exposure to radiation (beta decay) with short $\left(\mathrm{t}^{1} 1 / 2=157 \mathrm{~min}\right)$ or long $\left(\mathrm{t}^{1} / 2=153\right.$ years $)$ half-lives, respectively. Using a stable isotope such as ${ }^{29} \mathrm{Si}$ would avoid radioactive exposure but it has a high natural abundance (ca. $5 \%$ of all endogenous $\mathrm{Si}(\mathrm{OH})_{4}$ ). Hence, a relatively accurate balance, as now proven is possible in this study, will be key to the success of the follow on stable isotope work. Moreover, with recent developments in inductively coupled plasma - mass spectrometry methods, to measure ${ }^{28} \mathrm{Si}$ and ${ }^{29} \mathrm{Si}$ in biological samples [28], we are confident that it will now be possible to discriminate the source of excreted Si (i.e. all 'washed through' following ingestion or some from the body pool following exchange with absorbed silicon). Both this question and that of $\mathrm{Si}$ retention following oral $\mathrm{Si}$ challenge to Si-depleted volunteers are big questions in 
Table 3 Silicon intake, excretion, and balance over $24 \mathrm{~h}$ period (study day 1)

\begin{tabular}{|c|c|c|c|c|}
\hline & \multicolumn{2}{|c|}{ Control group $(n=6)$} & \multicolumn{2}{|c|}{ Si-supplemented group $(n=6)$} \\
\hline & Mean \pm SD & Range & Mean \pm SD & Range \\
\hline \multicolumn{5}{|l|}{ Silicon intake } \\
\hline Si supplement (mg) & - & & 28.89 & \\
\hline Dietary Si intake (mg) & 23.86 & & 23.86 & \\
\hline Total Si intake (mg/24 h) & 23.86 & & 52.75 & \\
\hline \multicolumn{5}{|l|}{ Silicon excretion } \\
\hline Urinary Si (mg/24 h) & $13.34 \pm 2.48$ & $(11.36-18.21)$ & $29.41 \pm 3.55$ & $(25.44-35.78)$ \\
\hline Faecal Si (mg/24 h) & $10.74 \pm 1.41$ & $(8.74-12.02)$ & $19.96 \pm 4.58$ & $(14.31-25.53)$ \\
\hline Total excretion (mg/24 h) & $23.77 \pm 1.94$ & $(21.62-26.95)$ & $50.02 \pm 4.98$ & $(43.93-55.68)$ \\
\hline Silicon balance $(\mathrm{mg})$ & $0.09 \pm 1.94$ & $(-3.09-2.24)$ & $2.73 \pm 4.98$ & $(-2.93-8.82)$ \\
\hline
\end{tabular}

human Si metabolism and this study proves that they may now be answered with carefully designed isotopic balance studies in Si replete and deplete individuals. In the work presented herein subjects were carefully matched to reduce variability between the two groups, however a cross-over design is undoubtedly more robust to really minimise inter-individual variation in silicon handling $[29,30]$. Thus, although more burdensome to the subjects, for the future work a cross-over study design will be seriously considered.

Finally, measurement of faecal Si excretion for the first time in a human study, as we report here, allowed the absolute absorption of $\mathrm{Si}$ from the orthosilicic acid dose solution to be estimated which, at $61 \pm 9 \%$ of the ingested dose, is similar to the estimate from total urinary Si output over the $24 \mathrm{~h}$ collection period $(57 \pm 10 \%)$. These estimates are comparable with previous data (absorption being stated as $\sim 50-60 \%$ of the ingested dose) from shorter urine collections, $0-6$ or $0-8$ h post-dose [20,25,29-34]. Hence, we can conclude that (a) urinary silicon does measure silicon absorption following oral $\mathrm{Si}$ challenge and (b) in general $0-6$ or $0-8 \mathrm{~h}$ urinary collections are adequate to estimate absorption/bioavailability of Si from readily absorbed dietary sources, supplements and test solutions (Si materials requiring prolonged digestion prior to absorption may differ in this respect as previously noted [30].

\section{Conclusions}

In conclusion the present study reports that urinary and faecal $\mathrm{Si}$ excretion can be measured with high precision (with inter-subject variance $\sim 6 \%$ ) and that in normal healthy subjects who are presumed to be in Si balance, ingestion of a soluble dose of $\mathrm{Si}$ results in an equivalent quantity being excreted within $24 \mathrm{~h}$. We confirm that urinary silicon may be used as an accurate measure of silicon absorption, assuming robust study design. This work also provides clear evidence that a proper isotopebased balance study can now be undertaken in silicon replete and depleted volunteers to inform on homeostasis of silicon and thus provide strong evidence (or not) for beneficial utilisation of the element by humans.

\section{Abbreviations}

AUC: Area under the (serum) curve; $\mathrm{HCl}$ : Hydrochloric acid; $\mathrm{HNO}_{3}$ : Nitric acid; ICP-OES: Inductively coupled plasma-optical emission spectrometry; OSA: Orthosilicic acid; SD: Standard deviation; Si: Silicon; Si $(\mathrm{OH})$ : Orthosilicic acid; UHP: Ultra-high purity.

\section{Competing interests}

All authors declare that they have no competing interests.

\section{Authors' contributions}

The authors' contributions were as follows: SSP, AS and RJ designed the research; SS conducted the research; RJ and AS had study oversight; SSP and RJ analysed the data; SSP, JJP and RJ wrote the paper \& had primary responsibility for final content. All authors read and approved the final manuscript.

\section{Acknowledgements}

This study was supported by the Office of Higher Education Commission, Thailand Research Fund and core institutional funds: Medical Research Council (grant number MC_US_A090_0008/Unit Programme number U1059).

\section{Author details}

${ }^{1}$ Faculty of Science and Technology, Loei Rajabhat University, Loei-Chiangkan Road, A. Muang, Loei 42000, Thailand. ${ }^{2}$ Applied Analytical and Inorganic Chemistry Program, Department of Chemistry, Faculty of Science, Mahidol University, Rajthevee, Bangkok 10400, Thailand. ${ }^{3}$ MRC Human Nutrition Research, Elsie Widdowson Laboratory, Fulbourn Road, Cambridge CB1 9NL, UK.

Received: 27 September 2013 Accepted: 27 December 2013 Published: 9 January 2014

\section{References}

1. Hildebrand M, Volcani BE, Gassman W, Schroeder Jl: A gene family of silicon transporters. Nature 1997, 385:688-689.

2. Uriz MJ, Turon $X$, Becerro MA: Silica deposition in Demosponges: spiculogenesis in Crambecrambe. Cell Tissue Res 2000, 301:299-309.

3. Epstein E: Silicon. Annu Rev Plant Physiol Plant Mol Biol 1999, 50:641-664.

4. Ma JF, Yamaji N, Mitani-Ueno N: Transport of silicon from roots to panicles in plants. Proc Jpn Acad Ser B Phys Sci 2011, 87:377-385.

5. Pennington JA: Silicon in foods and diets. Food Addit Contam 1991, 8:97-118.

6. Van Dyck K, Van Cauwenbergh R, Robberecht H, Deelstra H: Bioavailability of silicon from food and food supplements. Fresenius J Anal Chem 1999, 363:541-544.

7. Jugdaohsingh $\mathrm{R}$, Anderson $\mathrm{SH}$, Tucker $\mathrm{KL}$, Elliott $\mathrm{H}$, Kiel DP, Thompson RP, Powell JJ: Dietary silicon intake and absorption. Am J Clin Nutr 2002, 75:887-893 
8. McNaughton SA, Bolton-Smith C, Mishra GD, Jugdaohsingh R, Powell JJ: Dietary silicon intake in post-menopausal women. Br J Nutr 2005, 94:813-817.

9. Jugdaohsingh R, Kinrade SD, Powell JJ: Is There a Biochemical Role for Silicon. In Metal lons in Biology and Medicine, vol X. Edited by Collery P, Brätter P, Negretti De Brätter V, Khassanova L, Etienne JC. Paris: John Libbey Euro Text; 2008:45-55.

10. Nielsen FH: Nutritional requirements for boron, silicon, vanadium, nickel, and arsenic: current knowledge and speculation. FASEB J 1991, 5:2661-2667.

11. Carlisle EM: Silicon: an essential element for the chick. Science 1972, 178:619-621.

12. Schwarz K, Milne DB: Growth-promoting effects of silicon in rats. Nature 1972, 239:333-334.

13. Jugdaohsingh R, Tucker KL, Qiao N, Cupples LA, Kiel DP, Powell JJ: Dietary silicon intake is positively associated with bone mineral density in men and premenopausal women of the Framingham Offspring cohort. J Bone Miner Res 2004, 19:297-307.

14. Jugdaohsingh R: Silicon and bone health. J Nutr Health Aging 2007, 11:99-110.

15. Jugdaohsingh R, Calomme MR, Robinson K, Nielsen F, Anderson SHC, D'Hease P, Geutsens P, Loveridge N, Thompson RPH, Powell JJ: Increased longitudinal growth in rats on a silicon-depleted diet. Bone 2008, 43:596-606

16. Jugdaohsingh R, Calomme MR, Robinson K, Nielsen F, Anderson SHC, D'Hease P, Geutsens P, Loveridge N, Thompson RPH, Powell JJ: Letter to the Editor: reply to Dr Exley comments on: Jugdaohsingh R et al., increased longitudinal growth in rats on a silicon depleted diet. Bone 2009, 44:1019-1020.

17. Mertz W: Use and misuse of balance studies. J Nutr 1987, 117:1811-1813.

18. Powell JJ, McNaughton SA, Jugdaohsingh R, Anderson SH, Dear J, Khot F, Mowatt L, Gleason KL, Sykes M, Thompson RPH, Bolton-Smith C, Hodson MJ: A provisional database for the silicon content of foods in the United Kingdom. Br J Nutr 2005, 94:804-812.

19. Burden TJ, Powell JJ, Taylor PD, Thompson RP: Optical accuracy, precision and sensitivity of inductively coupled plasma optical emission spectrometry: bioanalysis of aluminium. J Anal At Spectrom 1995, 10:259-266.

20. Sripanyakorn S, Jugdaohsingh R, Elliott H, Walker C, Mehta P, Shoukru S, Thompson RP, Powell JJ: The silicon content of beer and its bioavailability in healthy volunteers. Br J Nutr 2004, 91:403-409.

21. Abramowitz M, Stegun IA: Handbook of mathematical functions. New York: Dover Publications; 1972

22. Jackson MJ, Jones DA, Edwards RH, Swainbank IG, Coleman ML: Zinc homeostasis in man: studies using a new stable isotope-dilution technique. Br J Nutr 1984, 51:199-208.

23. Roffey SJ, Obach RS, Gedge Jl, Smith DA: What is the objective of the mass balance study? A retrospective analysis of data in animal and human excretion studies employing radiolabeled drugs. Drug Metab Rev 2007, 39:17-43.

24. Palacios C, Wigertz K, Braun M, Martin BR, McCabe GP, McCabe L, Pratt JH, Peacock M, Weaver CM: Magnesium retention from metabolic-balance studies in female adolescents: impact or race, dietary salt, and calcium. Am J Clin Nutr 2013, 97:1014-1019.

25. Reffitt DM, Jugdaohsingh R, Thompson RP, Powell JJ: Silicic acid: its gastrointestinal uptake and urinary excretion in man and effects on aluminium excretion. J Inorg Biochem 1999, 76:141-147.

26. D'Haese PC, Shaheen FA, Huraid SO, Djukanovic L, Polenakovic MH, Spasovski G, Shikole A, Schurgers ML, Daneels RF, Lamberts LV, Van Landeghem GF, De Broe ME: Increased silicon levels in dialysis patients due to high silicon content in the drinking water, inadequate water treatment procedures, and concentrate contamination: a multicentre study. Nephrol Dial Transplant 1995, 10:1838-1844.

27. Berndt T, Kumar R: Phosphatonins and the regulation of phosphate homeostasis. Annu Rev Physiol 2007, 69:341-359.

28. Koller D, Ratcliffe S, Jugdaohsingh R, Powell JJ, Bruggraber SF: Optimisation of Operative Conditions for the Determination of Silicon Concentrations in in Vitro and ex Vivo Biological Matrices by DRC-ICP-MS. Krakow, Poland: Winter Conference on Plasma Spectrochemistry; 2013.
29. Jugdaohsingh R, Reffitt DM, Oldham C, Day JP, Fifield LK, Thompson RPH, Powell JJ: Oligomeric but not monomeric silica prevents aluminium absorption in human. Amer J Clin Nutr 2000, 71:944-949.

30. Jugdaohsingh R, Hui M, Anderson SH, Kinrade SD, Powell JJ: The silicon supplement 'Monomethylsilanetriol' is safe and increases the body pool of silicon in healthy pre-menopausal women. Nutr Metab (Lond) 2013, 10:37.

31. Jugdaohsingh R, Sripanyakorn S, Powell JJ: Silicon absorption and excretion is independent of age and sex in adults. Br J Nutr 2013, 25:1-7 [Epub ahead of print].

32. Sripanyakorn S, Jugdaohsingh R, Dissayabutr W, Anderson SHC, Thompson $\mathrm{RPH}$, Powell JJ: The comparative absorption of silicon from different foods and food supplements. Br J Nutr 2009, 102:825-834.

33. Bellia JP, Birchall JD, Roberts NB: The role of silicic acid in the renal excretion of aluminium. Ann Clin Lab Sci 1996, 26:227-233.

34. Calomme MR, Cos P, D'Haese PC, Vingerhoets R, Lamberts LV, De Broe ME, Van Hoorebeke C, VandenBerghe DA: Absorption of Silicon in Healthy Subjects. In Metal lons in Biology and Medicine, vol V. Edited by Collery P, Brätter P, Negretti De Brätter V, Khassanova L, Etienne JC. Paris: John Libbey Euro Text; 1998:228-232.

doi:10.1186/1743-7075-11-4

Cite this article as: Pruksa et al:: Silicon balance in human volunteers; a pilot study to establish the variance in silicon excretion versus intake. Nutrition \& Metabolism 2014 11:4

\section{Submit your next manuscript to BioMed Central and take full advantage of:}

- Convenient online submission

- Thorough peer review

- No space constraints or color figure charges

- Immediate publication on acceptance

- Inclusion in PubMed, CAS, Scopus and Google Scholar

- Research which is freely available for redistribution

Submit your manuscript at www.biomedcentral.com/submit
C) Biomed Central 